Article

\title{
Tricholides A and B and Unnarmicin D: New Hybrid PKS-NRPS Macrocycles Isolated from an Environmental Collection of Trichodesmium thiebautii
}

\author{
Matthew J. Bertin ${ }^{1, *}$, Alexandre F. Roduit ${ }^{1}$, Jiadong Sun ${ }^{1}$, Gabriella E. Alves ${ }^{1}$, \\ Christopher W. Via ${ }^{1}$, Miguel A. Gonzalez ${ }^{1}$, Paul V. Zimba ${ }^{2}$ and Peter D. R. Moeller ${ }^{3}$ \\ 1 Department of Biomedical and Pharmaceutical Sciences, College of Pharmacy, University of Rhode Island, \\ Kingston, RI 02881, USA; aroduit@my.uri.edu (A.F.R.); jiadong_sun@my.uri.edu (J.S.); \\ gabriella_alves@my.uri.edu (G.E.A.); Christopher_via@my.uri.edu (C.W.V.); miggyg6@my.uri.edu (M.A.G.) \\ 2 Center for Coastal Studies and Department of Life Sciences, Texas A\&M Corpus Christi, 6300 Ocean Drive, \\ Corpus Christi, TX 78412, USA; paul.zimba@tamucc.edu \\ 3 Emerging Toxins Program, National Ocean Service/NOAA, Hollings Marine Laboratory, \\ 331 Fort Johnson Road, Charleston, SC 29412, USA; peter.moeller@noaa.gov \\ * Correspondence: mbertin@uri.edu; Tel.: +1-401-874-5016
}

Received: 10 May 2017; Accepted: 27 June 2017; Published: 30 June 2017

\begin{abstract}
Bioassay-guided isolation of the lipophilic extract of Trichodesmium thiebautii bloom material led to the purification and structure characterization of two new hybrid polyketide-non-ribosomal peptide (PKS-NRPS) macrocyclic compounds, tricholides A and B (1 and 2). A third macrocyclic compound, unnarmicin D (3), was identified as a new depsipeptide in the unnarmicin family, given its structural similarity to the existing compounds in this group. The planar structures of $\mathbf{1 - 3}$ were determined using 1D and 2D NMR spectra and complementary spectroscopic and spectrometric procedures. The absolute configurations of the amino acid components of 1-3 were determined via acid hydrolysis, derivitization with Marfey's reagent and HPLC-UV comparison to authentic amino acid standards. The absolute configuration of the 3-hydroxydodecanoic acid moiety in $\mathbf{3}$ was determined using a modified Mosher's esterification procedure on a linear derivative of tricharmicin (4) and additionally by a comparison of ${ }^{13} \mathrm{C}$ NMR shifts of 3 to known depsipeptides with $\beta$-hydroxy acid subunits. Tricholide B (2) showed moderate cytotoxicity to Neuro-2A murine neuroblastoma cells $\left(\mathrm{EC}_{50}: 14.5 \pm 6.2 \mu \mathrm{M}\right)$.
\end{abstract}

Keywords: Trichodesmium thiebautii; macrocycle; depsipeptide; cyanobacteria

\section{Introduction}

Marine cyanobacteria have been fertile grounds for the isolation of a diverse array of structurally intriguing secondary metabolites with a broad-spectrum of biological activities [1-4]. A notable class of these compounds are the macrocyclic hybrid polyketide-non-ribosomal peptides (PKS-NRPS). The hybrid macrocycles isolated from cyanobacteria display unique and rare structural elements and functionalities, such as the dichlorinated beta-hydroxy acid and thiazole carboxylic acid units in the peptolide lyngbyabellin [5] and a rare $\mathrm{N}$-methyl enamide of sanctolide A [6]. Macrocycles have been prolific structures in drug discovery, perhaps most notably as antibiotics [7]. However, this class displays diverse bioactivities including antitumor [8], antimalarial [9] and neuroactive properties, including sodium channel inhibition [10].

Many cyanobacterial macrocycles are peptides and depsipeptides [11] derived from NRPS or mixed NRPS-PKS genetic architecture and encode proteins with the ability to incorporate L- and D- $\alpha$-amino acids as well as $\beta$-hydroxy fatty acids [12,13]. $\beta$-hydroxyacyl incorporation 
has been observed in several microbial depsipeptides including the beauverolides [14-16] ( 3 and 4 residue macrocycles); the unnarmicins [17], the solonamides [18], the arthroamides [19], the turnagainolides [20], and ngercheumicin C, D and E [21] (five residue macrocycles); and scytonemide B [22] and kailuin A-H (six residue macrocycles) [23,24]. These macrocycles have generally displayed antibiotic activity [17], quorum sensing interference [18] and weak cytotoxicity [24].

In this work, we detail the isolation and structure characterization of three new additions (1-3) to the PKS-NRPS macrocycles from Trichodesmium thiebautii bloom biomass. Trichodesmium spp. have been a relatively underexplored source of secondary metabolites. The cyclic peptide trichamide was isolated from a cultured specimen of Trichodesmium erythraeum IMS101 [25]. Trichophycin A and the trichotoxins, chlorinated polyketides have been isolated from environmental collections of Trichodesmium thiebautii [26,27]. Two of these metabolites in the current work, tricholides A and B (1 and 2), represent a new class of polyketide macrolactones, each incorporating a single proline residue and predicted 2-methylhexanoic acid residue. The third compound, unnarmicin D, departs from previously described unnarmicins by featuring a 3-hydroxydodecanoic acid residue.

\section{Results}

\subsection{Isolation and Structure Determination of 1-3}

Bioassy-guided isolation of the lipophilic extract of Trichodesmium thiebautii bloom material using human colon cancer HCT-116 cells identified a mixed fraction that showed potent cytotoxicity at a single dose of $40 \mu \mathrm{g} / \mathrm{mL}$. Subsequent purification of the fraction using HPLC resulted in the isolation of 1 . HRESIMS analysis of 1 identified a pseudomolecular ion $[\mathrm{M}+\mathrm{H}]^{+}$at $m / z 408.3113$ suggesting a molecular formula of $\mathrm{C}_{24} \mathrm{H}_{41} \mathrm{NO}_{4}$ and five degrees of unsaturation. Examination of the ${ }^{13} \mathrm{C} N M R$, HSQC and HMBC spectra identified two signals consistent with that of ester or amide functionalities, two alkene signals, two oxymethine carbons, three methine carbons, eleven methylene signals, and four methyl signals, one of which was consistent with that of an $O$-methyl $\left(\delta_{\mathrm{C}} 56.0\right)$.

Examination of 1D and 2D NMR spectra (Figures S1-S7; Table 1) allowed for the construction of two partial structures. In the first partial structure, a methine proton signal $\left(\mathrm{H}-2, \delta_{\mathrm{H}} 4.50\right)$ showed COSY correlations to a diastereotopic methylene group (H-3a, $\delta_{\mathrm{H}} 2.29$ and $\left.\mathrm{H}-3 \mathrm{~b}, \delta_{\mathrm{H}} 2.10\right)$ and TOCSY correlations to two additional methylene groups $\left(\mathrm{H}_{2}-4, \delta_{\mathrm{H}} 1.94 ; \mathrm{H}-5 \mathrm{a}, \delta_{\mathrm{H}} 3.77 ; \mathrm{H}-5 \mathrm{~b}, \delta_{\mathrm{H}} 3.62\right)$. Examining the ${ }^{13} \mathrm{C}$ NMR values of $\mathrm{C}-2, \mathrm{C}-3, \mathrm{C}-4, \mathrm{C}-5\left(\delta_{\mathrm{C}} 59.1,31.8,22.3,46.7\right)$, we identified the first spin system as the amino acid proline. An HMBC correlation from H-2 to $\mathrm{C}-1\left(\delta_{\mathrm{C}} 172.2\right)$ firmly established the $\alpha$ amino acid and satisfied two degrees of unsaturation. The second partial structure was comprised of a polarized olefin $\left(C-7, \delta_{C} 117.1 ; C-8, \delta_{C} 151.1\right)$ that showed HMBC correlations to C-6 $\left(\delta_{\mathrm{C}} 173.0\right)$ consistent with that of an $\alpha, \beta$-unsaturated carbonyl functionality, satisfying the third and fourth degree of unsaturation. The distal proton in the olefin $\left(\mathrm{H}-8, \delta_{\mathrm{H}} 7.16\right)$ showed a COSY correlation to $\mathrm{H}-9\left(\delta_{\mathrm{H}} 2.34\right)$. $\mathrm{H}-9$ showed COSY correlations to a methyl signal $\left(\mathrm{H}-24, \delta_{\mathrm{H}} 1.04\right)$ and a methylene $\left(\mathrm{H}_{2}-10, \delta_{\mathrm{H}} 1.36\right)$. The $\mathrm{H}_{2}-10$ methylene signal was correlated by TOCSY to second methylene group $\left(\mathrm{H}-11 \mathrm{a}, \delta_{\mathrm{H}} 1.62 ; \mathrm{H}-11 \mathrm{~b}, \delta_{\mathrm{H}} 1.43\right)$ and an oxymethine proton $\left(\mathrm{H}-12, \delta_{\mathrm{H}} 3.20\right)$. Bidirectional COSY correlations established three methylene groups between $\mathrm{H}-12$ and a second deshielded oxymethine (H-16, $\left.\delta_{\mathrm{H}} 4.98\right)$. $\mathrm{H}-16$ showed COSY correlations to $\mathrm{H}-17\left(\delta_{\mathrm{H}} 1.60\right)$ and $\mathrm{H}-17$ showed COSY correlations to a methyl $\left(\mathrm{H}_{3}-22, \delta_{\mathrm{H}} 0.91\right)$ and a methylene group $\left(\mathrm{H}-18 \mathrm{a}, \delta_{\mathrm{H}} 1.34 ; \mathrm{H}-18 \mathrm{~b}, \delta_{\mathrm{H}} 1.10\right)$. Bidirectional COSY correlations from $\mathrm{H}_{2}-18$ to the terminal methyl $\mathrm{H}_{3}-21\left(\delta_{\mathrm{H}} 0.89\right)$ established two additional methylene groups in the alkyl chain $\left(\mathrm{H}-19 \mathrm{a}, \delta_{\mathrm{H}} 1.30 ; \mathrm{H}-19 \mathrm{~b}, \delta_{\mathrm{H}} 1.26 ; \mathrm{H}_{2}-20, \delta_{\mathrm{H}} 1.28\right)$ and completed the core of the second partial structure. An HMBC correlation from $\mathrm{H}_{3}-23\left(\delta_{\mathrm{H}} 3.27\right)$ to $\mathrm{C}-12\left(\delta_{\mathrm{C}} 79.9\right)$ established an $\mathrm{O}$-methyl group in the second partial structure. $\mathrm{HMBC}$ correlations from $\mathrm{H}_{2}-5$ to $\mathrm{C}-6$ connected the two partial structures and the HMBC correlation from $\mathrm{H}-16$ to $\mathrm{C}-1$ demonstrated that 1 was a macrolactone featuring a proline residue and satisfied the final degree of unsaturation (Figure 1). 
Table 1. NMR data for tricholide $\mathrm{A}(\mathbf{1})^{\mathrm{a}}\left(\mathrm{CDCl}_{3}\right)$.

\begin{tabular}{|c|c|c|c|c|}
\hline Position & $\delta_{\mathrm{C}}$ & $\delta_{\mathrm{H}}(J$ in $\mathrm{Hz})$ & HMBC & COSY \\
\hline 1 & $172.2, \mathrm{qC}$ & & & \\
\hline 2 & $59.1, \mathrm{CH}$ & $4.50, \mathrm{dd}(9.0,2.0)$ & $1,3,4,5$ & $3 a, 3 b$ \\
\hline $3 a$ & $31.8, \mathrm{CH}_{2}$ & $2.29, \mathrm{~m}$ & $1,2,4$ & $2,3 b, 4$ \\
\hline $3 b$ & & $2.10, \mathrm{~m}$ & $1,4,5$ & $3 a, 4$ \\
\hline 4 & 22.3, $\mathrm{CH}_{2}$ & $1.94, \mathrm{~m}$ & $2,3,5$ & $3 a, 5 a, 5 b$ \\
\hline $5 a$ & $46.7, \mathrm{CH}_{2}$ & $3.77, \mathrm{~m}$ & $2,3,4,6$ & $4,5 b$ \\
\hline $5 b$ & & $3.62, \mathrm{~m}$ & $2,3,4,6$ & $4,5 a$ \\
\hline 6 & $165.2, \mathrm{qC}$ & & & \\
\hline 7 & 117.1, CH & $5.84, \mathrm{~d}(15.5)$ & $6,8,9,24$ & 8 \\
\hline 8 & 151.1, CH & 7.16, dd $(15.5,5.8)$ & $6,7,9,10,24$ & 7,9 \\
\hline 9 & $35.9, \mathrm{CH}$ & $2.34, \mathrm{~m}$ & $7,8,10,24$ & $8,10,24$ \\
\hline 10 & $30.3, \mathrm{CH}_{2}$ & $1.36, \mathrm{~m}$ & $8,9,11$ & 9 \\
\hline $11 \mathrm{a}$ & $30.9, \mathrm{CH}_{2}$ & $1.62, \mathrm{~m}$ & 10,12 & $11 b, 12$ \\
\hline $11 b$ & & 1.43, ovlp $^{b}$ & 10,12 & 12 \\
\hline 12 & $79.9, \mathrm{CH}$ & $3.20, \mathrm{~m}$ & $11,13,14,23$ & $11 b, 13 a$ \\
\hline $13 a$ & $30.0, \mathrm{CH}_{2}$ & $1.55, \mathrm{~m}$ & 12,14 & $12,13 b, 14 b$ \\
\hline $13 b$ & & 1.43, ovlp & 12,14 & $12,13 a, 14 b$ \\
\hline $14 a$ & $19.6, \mathrm{CH}_{2}$ & $1.40, \mathrm{~m}$ & $13,15,16$ & $13 \mathrm{~b}, 14 \mathrm{a}$ \\
\hline $14 \mathrm{~b}$ & & $1.16, \mathrm{~m}$ & 15,16 & $13 a, 14 a$ \\
\hline $15 a$ & $32.7, \mathrm{CH}_{2}$ & $1.57, \mathrm{~m}$ & 14,16 & $14 b, 15 b, 16$ \\
\hline $15 b$ & & $1.47, \mathrm{~m}$ & 14,16 & $14 b, 15 a, 16$ \\
\hline 16 & $78.3, \mathrm{CH}$ & 4.98, ddd $(10.6,4.6)$ & $1,14,15,17,22$ & $15 a, 15 b, 17$ \\
\hline 17 & $37.5, \mathrm{CH}$ & $1.60, \mathrm{~m}$ & $16,18,19,22$ & $16,18 b, 22$ \\
\hline $18 \mathrm{a}$ & $32.9, \mathrm{CH}_{2}$ & 1.34, ovlp & 17,19 & $17,18 b$ \\
\hline $18 \mathrm{~b}$ & & $1.10, \mathrm{~m}$ & 17,19 & $17,18 \mathrm{a}$ \\
\hline $19 a$ & $29.2, \mathrm{CH}_{2}$ & 1.30, ovlp & 18,20 & \\
\hline $19 b$ & & 1.26, ovlp & 18,20 & $18 b$ \\
\hline 20 & $22.9, \mathrm{CH}_{2}$ & 1.28, ovlp & 21 & 21 \\
\hline 21 & $14.0, \mathrm{CH}_{3}$ & $0.89, \mathrm{t}(7.1)$ & 19,20 & 20 \\
\hline 22 & $14.7, \mathrm{CH}_{3}$ & $0.91, \mathrm{~d}(6.8)$ & $16,17,18$ & 17 \\
\hline 23 & $56.0, \mathrm{CH}_{3}$ & $3.27, \mathrm{~s}$ & 12 & \\
\hline 24 & $22.5, \mathrm{CH}_{3}$ & $1.04, \mathrm{~d}(7.0)$ & $8,9,10$ & 9 \\
\hline
\end{tabular}

a $800 \mathrm{MHz}$ for ${ }^{1} \mathrm{H}, 200 \mathrm{MHz}$ for ${ }^{13} \mathrm{C} ;{ }^{\text {b }}$ overlapping signals.

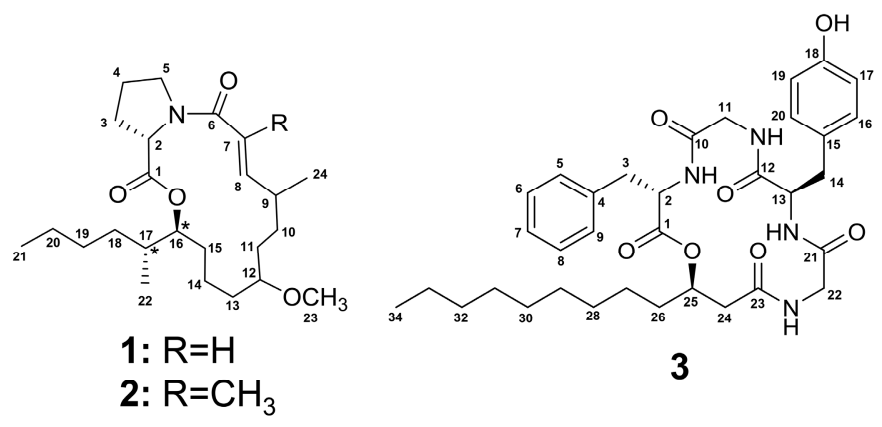

Figure 1. Structures of tricholide A (1), tricholide B (2) and unnarmicin D (3). The configuration of C-16 and C-17 in $\mathbf{1}$ and $\mathbf{2}$ is relative and noted by $\left(^{*}\right)$.

HRESIMS of 2 identified a pseudomolecular ion $[\mathrm{M}+\mathrm{H}]^{+}$at $m / z 422.3270$ suggesting a molecular formula of $\mathrm{C}_{25} \mathrm{H}_{43} \mathrm{NO}_{4}$ and five degrees of unsaturation as in 1 . The proton and carbon NMR spectra of 2 were nearly identical to 1 and the mass difference of 14 strongly suggested the addition of a $\mathrm{CH}_{2}$ group or methyl group instead of a proton in 2. Examination of the ${ }^{1} \mathrm{H} \mathrm{NMR},{ }^{13} \mathrm{C} N M R$ and $2 \mathrm{D}$ spectra of 2 (Figures S8-S14) showed a new singlet methyl signal $\left(\mathrm{H}_{3}-25, \delta_{\mathrm{H}} 1.84\right)$ instead of the doublet signal H-7 $\left(\delta_{\mathrm{H}} 7.16\right)$ in $\mathbf{1}$. The ${ }^{13} \mathrm{C}$ NMR spectrum showed one new signal $\left(\mathrm{C}-25, \delta_{\mathrm{C}} 14.8\right)$ (Table S1). 
HMBC correlations from $\mathrm{H}_{3}-25$ to C-6, C-7 and C-8 firmly established the methyl substitution at C-7 in 2.

The relative configuration of the olefin in $\mathbf{1}$ was determined to be $E$ by virtue of the large vicinal coupling constant between $\mathrm{H}-7$ and $\mathrm{H}-8(\mathrm{~J}=15.5 \mathrm{~Hz})$. The relative configuration between $\mathrm{C}-16$ and $\mathrm{C}-17$ was determined by examining the extracted ${ }^{1} \mathrm{H}-{ }^{1} \mathrm{H}$ coupling constant between $\mathrm{H}-16$ and $\mathrm{H}-17$. A large coupling constant of $10.6 \mathrm{~Hz}$ supported an anti-configuration. The relative configuration of 2 was identical to that of $\mathbf{1}$.

The absolute configuration of the proline residues in $\mathbf{1}$ and $\mathbf{2}$ was determined by comparing the HPLC retention times of authentic L- and D/L-amino acid standards and the acid hydrolyzed constituents of $\mathbf{1}$ and $\mathbf{2}$ each reacted with Marfey's reagent (L-FDVA). The hydrolyzate of both $\mathbf{1}$ and $\mathbf{2}$ showed retention times ( $\mathrm{min}$ ) that matched L-Pro (13.00; see Experimental Section and Figures S22 and S23). The small quantities of $\mathbf{1}$ and $\mathbf{2}$ isolated precluded further analysis of absolute configuration.

HRESIMS analysis of 3 identified a pseudomolecular ion $[\mathrm{M}+\mathrm{H}]^{+}$at $m / z 623.3436$ suggesting a molecular formula of $\mathrm{C}_{34} \mathrm{H}_{46} \mathrm{~N}_{4} \mathrm{O}_{7}$ requiring 14 degrees of unsaturation. The peptidic nature of 3 was supported by five signals in the ${ }^{13} \mathrm{C}$ NMR spectrum consistent with those of esters or amides $\left(\delta_{\mathrm{C}} 168.2,170.1,170.7,171.3,172.4\right)$ (Figure S16) and the examination of the ${ }^{1} \mathrm{H}$ NMR spectrum with doublets for four amide protons $\left(\delta_{\mathrm{H}} 8.98,8.61,8.02\right.$ and 7.40) (Figure S15) accounting for five out of the seven oxygen atoms present and the four nitrogen atoms.

Analysis of 2D NMR data (Figures S17-S21) allowed two spin systems to be established (cf. Table 2 and Figure 2) as likely Gly residues. COSY data correlated an $\mathrm{NH}$ proton $\left(\mathrm{NH}-3, \delta_{\mathrm{H}} 8.98\right)$ to a methine proton $\left(\mathrm{H}-13, \delta_{\mathrm{H}} 4.13\right)$ which itself was correlated to a diastereotopic methylene group $\left(\mathrm{H}-14 \mathrm{a}, \delta_{\mathrm{H}} 3.02\right.$ and $\left.\mathrm{H}-14 \mathrm{~b}, \delta_{\mathrm{H}} 2.78\right)$. An HMBC correlation from the methylene group to a quaternary carbon (C-15, $\left.\delta_{\mathrm{C}} 127.8\right)$ and chemically equivalent carbons (C-16/20, $\left.\delta_{\mathrm{C}} 129.8\right)$ established a connection to an aromatic ring. The remaining carbons of the ring were comprised of chemically equivalent carbons $(C-17 / 19$, $\left.\delta_{\mathrm{C}} 115.1\right)$ bearing methine protons $\left(\mathrm{H}-17 / 19, \delta_{\mathrm{H}} 6.69, \mathrm{~d}, J=8.5 \mathrm{~Hz}\right)$ and a quaternary carbon $(\mathrm{C}-20$, $\left.\delta_{\mathrm{C}} 156.0\right)$ which strongly supported a Tyr residue. Additionally, COSY data correlated an NH proton $\left(\mathrm{NH}-1, \delta_{\mathrm{H}} 7.40\right)$ to a methine proton $\left(\mathrm{H}-2, \delta_{\mathrm{H}} 4.58\right)$ which itself was correlated to a second diastereotopic methylene group $\left(\mathrm{H}-3 \mathrm{a}, \delta_{\mathrm{H}} 3.15\right.$ and $\left.\mathrm{H}-3 \mathrm{~b}, \delta_{\mathrm{H}} 2.78\right)$. An $\mathrm{HMBC}$ correlation from this methylene group to a quaternary carbon $\left(\mathrm{C}-4, \delta_{\mathrm{C}} 137.6\right)$ and ${ }^{1} \mathrm{H}-{ }^{1} \mathrm{H}$ couplings between five methine protons on this second aromatic ring (C5-C9) supported a Phe residue. HMBC correlations from amino acid $\alpha$-protons to their adjacent carbonyls allowed the assignment of four unmodified amino acids: Phe, Tyr, and two Gly residues (Figure 2). The presence of the two aromatic amino acids and five carbonyl functionalities accounted for 13 out of the 14 degrees of unsaturation. The final residue was comprised of a deshielded diastereotopic methylene group $\left(\mathrm{H}-24 \mathrm{a}, \delta_{\mathrm{H}} 2.60 ; \mathrm{H}-24 \mathrm{~b}, \delta_{\mathrm{H}} 2.19\right)$ which showed HMBC correlations to the $\mathrm{C}-23$ carbonyl $\left(\delta_{\mathrm{C}} 170.7\right)$ and an oxygen-bearing methine $\left(\mathrm{C}-25, \delta_{\mathrm{C}} 72.5\right)$. The oxymethine proton $\left(\mathrm{H}-25, \delta_{\mathrm{H}} 5.13\right)$ showed a COSY correlation to $\mathrm{H}_{2}-26\left(\delta_{\mathrm{H}} 1.54\right.$ and 1.46). Bidirectional HMBC and COSY correlations in addition to examination of the ${ }^{13} \mathrm{C}$ NMR spectrum extended the methylene chain to a terminal methyl $\left(\mathrm{H}_{3}-34, \delta_{\mathrm{H}} 0.87, t, J=7.2 \mathrm{~Hz}\right)$. The ${ }^{13} \mathrm{C}$ NMR spectrum showed four nearly chemically equivalent carbon signals (C-28 and C-29, $\delta_{\mathrm{C}} 28.9$; C-30 and C-31 $\left.\delta_{\mathrm{C}} 28.7\right)$ correlated by HSQC to a methylene envelope $\left(\delta_{\mathrm{H}} 1.22-1.25\right)$. While the overlapping methylenes made NMR correlations of individual signals difficult, the chemical shifts of these four remaining $\mathrm{CH}_{2}$ groups and the molecular formula of 3 supported assigning this final residue as 3-hydroxydodecanoic acid (3-Hdda) (Table 2).

The individual residue spin systems of 3 were connected using HMBC data. An HMBC correlation between the NH of Phe (NH-1, $\left.\delta_{\mathrm{H}} 7.40\right)$ and $\mathrm{C}-10\left(\delta_{\mathrm{C}} 168.2\right)$ of Gly-1 connected these two residues. An HMBC correlation between the $\mathrm{NH}$ proton $\left(\mathrm{NH}-2, \delta_{\mathrm{H}} 8.02\right)$ and $\mathrm{C}-12\left(\delta_{\mathrm{C}} 171.3\right)$ connected Gly-1 to Tyr. The NH proton of Tyr $\left(\mathrm{NH}-3, \delta_{\mathrm{H}} 8.98\right)$ showed an HMBC correlation to the carbonyl of Gly-2 $\left(\mathrm{C}-21, \delta_{\mathrm{C}} 172.4\right)$ and the $\mathrm{NH}\left(\mathrm{NH}-4, \delta_{\mathrm{H}} 8.61\right)$ of Gly-2 showed an HMBC correlation to C-23 $\left(\delta_{\mathrm{C}} 170.7\right)$ of the 3-Hdda residue. An HMBC correlation between the oxymethine H-25 $\left(\delta_{\mathrm{H}} 5.14\right)$ and C-1 $\left(\delta_{\mathrm{C}} 170.1\right)$ connected the fatty acid residue to the Phe residue, satisfied the final degree of unsaturation and 
established 3 as a cyclic depsipeptide featuring a 3-hydroxy fatty acid moiety. Thus, the planar structure of 3 was determined to be [3-Hdda-Gly-Tyr-Gly-Phe].

The absolute configuration of the $\alpha$-amino acids in 3 were determined using the Marfey's protocol described above. The hydrolyzate of 3 showed retention times (min) that matched L-Phe (13.56) and D-Tyr (11.93; see Experimental Section and Figure S24).

The absolute configuration of C-25 in the 3-Hdda residue was determined using a modified Mosher's esterification procedure [28] on a hydrolyzed linear derivative of unnarmicin D (4) (Figures S25 and S26). Positive $\Delta\left(\delta_{\mathrm{H}} S-\delta_{\mathrm{H}} R\right)$ values for $\mathrm{H}-27$ and $\mathrm{H}-26$ and negative $\Delta\left(\delta_{\mathrm{H}} S-\delta_{\mathrm{H}} R\right)$ values for $\mathrm{H}-24$ and $\mathrm{NH}-4$ supported an $25 R$ configuration (Figure $\mathrm{S} 27$ ).

Table 2. NMR data for unnarmicin D (3) a $\left(\right.$ DMSO- $\left.d_{6}\right)$.

\begin{tabular}{|c|c|c|c|c|c|}
\hline Residue & Position & $\delta_{\mathrm{C}}$ & Type $\delta_{\mathrm{H}}(J$ in $\mathrm{Hz})$ & НМBC & COSY \\
\hline \multirow[t]{9}{*}{ Phe } & 1 & $170.1, \mathrm{qC}$ & & & \\
\hline & 2 & $52.6 \mathrm{CH}$ & $4.58, \operatorname{td}(9.5,5.0)$ & $1,3,4,10$ & $3 a, 3 b, N H-1$ \\
\hline & $3 a$ & $36.5, \mathrm{CH}_{2}$ & $3.15, \mathrm{dd}(13.7,5.0)$ & $1,2,4,5,9$ & $2,3 b$ \\
\hline & $3 b$ & & 2.78, ovlp & $1,2,4,5,9$ & $2,3 a$ \\
\hline & 4 & 137.6, qC & & & \\
\hline & $5 / 9$ & $129.3, \mathrm{CH}$ & $7.20, \mathrm{~d}(7.2)$ & 3,7 & \\
\hline & $6 / 8$ & $128.0, \mathrm{CH}$ & $7.24, \mathrm{t}(7.2)$ & $4,5,9$ & \\
\hline & 7 & $126.2, \mathrm{CH}$ & $7.17, \mathrm{t}(7.2)$ & 5,9 & \\
\hline & NH-1 & & $7.40, \mathrm{~d}(9.3)$ & 2,10 & 2 \\
\hline \multirow[t]{4}{*}{ Gly-1 } & 10 & $168.2, \mathrm{qC}$ & & & \\
\hline & $11 \mathrm{a}$ & $42.1, \mathrm{CH}_{2}$ & $3.90, \mathrm{dd}(17.1,8.3)$ & 10,12 & $11 b, \mathrm{NH}-2$ \\
\hline & $11 b$ & & 3.37, dd $(17.1,4.6)$ & 10,12 & 11a, NH-2 \\
\hline & $\mathrm{NH}-2$ & & $8.02,(8.4,4.8)$ & 11,12 & $11 a, 11 b$ \\
\hline \multirow[t]{9}{*}{ Tyr } & 12 & $171.3, \mathrm{qC}$ & & & \\
\hline & 13 & $57.2, \mathrm{CH}$ & $4.13, \mathrm{~m}$ & $12,14,15,21$ & $14 a, 14 b, \mathrm{NH}-3$ \\
\hline & $14 a$ & $35.0, \mathrm{CH}_{2}$ & $3.02, \mathrm{dd}(14.3,3.8)$ & $12,13,15,16,20$ & $13,14 b$ \\
\hline & $14 \mathrm{~b}$ & & 2.78, ovlp & $12,13,15,16,20$ & $13,14 a$ \\
\hline & 15 & $127.8, \mathrm{qC}$ & & & \\
\hline & $16 / 20$ & $129.8, \mathrm{CH}$ & $7.13, \mathrm{~d}(8.5)$ & 14,18 & $17 / 19$ \\
\hline & $17 / 19$ & $115.1, \mathrm{CH}$ & $6.69, \mathrm{~d}(8.5)$ & 15,18 & $16 / 20$ \\
\hline & 18 & $156.0, \mathrm{qC}$ & & & \\
\hline & $\mathrm{NH}-3$ & & $8.98, \mathrm{~d}(5.5)$ & $13,14,21$ & 13 \\
\hline \multirow[t]{4}{*}{ Gly-2 } & 21 & $172.4, \mathrm{qC}$ & & & \\
\hline & $22 a$ & $42.7 \mathrm{CH}_{2}$ & $3.83, \mathrm{dd}(14.7,3.8)$ & 21,23 & $22 b, \mathrm{NH}-4$ \\
\hline & $22 b$ & & $3.51, \mathrm{dd}(14.7,6.8)$ & 21,23 & $22 \mathrm{a}, \mathrm{NH}-4$ \\
\hline & $\mathrm{NH}-4$ & & $8.61, \mathrm{dd}(6.8,3.9)$ & 22,23 & $22 a, 22 b$ \\
\hline \multirow[t]{14}{*}{ Hdda $^{b}$} & 23 & $170.7, \mathrm{qC}$ & & & \\
\hline & $24 a$ & $40.4, \mathrm{CH}_{2}$ & $2.60, \mathrm{dd}(13.7,3.6)$ & $23,25,26$ & $24 b, 25$ \\
\hline & $24 b$ & & $2.19, \mathrm{dd}(13.7,10.5)$ & $23,25,26$ & $24 \mathrm{a}, 25$ \\
\hline & 25 & $72.5, \mathrm{CH}$ & $5.14, \mathrm{~m}$ & $1,24,26,27$ & $24 b, 26 a, 26 b$ \\
\hline & $26 a$ & $33.8, \mathrm{CH}_{2}$ & $1.54, \mathrm{~m}$ & $24,25,27,28$ & $25,26 b, 27$ \\
\hline & $26 b$ & & $1.46, \mathrm{~m}$ & $24,25,27,28$ & $25,26 a, 27$ \\
\hline & 27 & $24.4, \mathrm{CH}_{2}$ & $1.16, \mathrm{~m}$ & $25,26,28$ & $26 a, 26 b$ \\
\hline & 28 & $28.9, \mathrm{CH}_{2}$ & 1.22, ovlp $^{\mathrm{c}}$ & & \\
\hline & 29 & $28.9, \mathrm{CH}_{2}$ & 1.22, ovlp & & \\
\hline & 30 & $28.7, \mathrm{CH}_{2}$ & 1.25, ovlp & & \\
\hline & 31 & 28.7, $\mathrm{CH}_{2}$ & 1.25 , ovlp & & \\
\hline & 32 & $31.3, \mathrm{CH}_{2}$ & 1.24, ovlp & $31,33,34$ & \\
\hline & 33 & $22.1, \mathrm{CH}_{2}$ & $1.28, \mathrm{~m}$ & 32,34 & 34 \\
\hline & 34 & $14.0, \mathrm{CH}_{3}$ & $0.87, \mathrm{t}(7.2)$ & 32,33 & 33 \\
\hline
\end{tabular}

a $800 \mathrm{MHz}$ for ${ }^{1} \mathrm{H}, 200 \mathrm{MHz}$ for ${ }^{13} \mathrm{C}^{\mathrm{b}}$ 3-hydroxydodecanoic acid; ${ }^{\mathrm{c}}$ overlapping signals. 

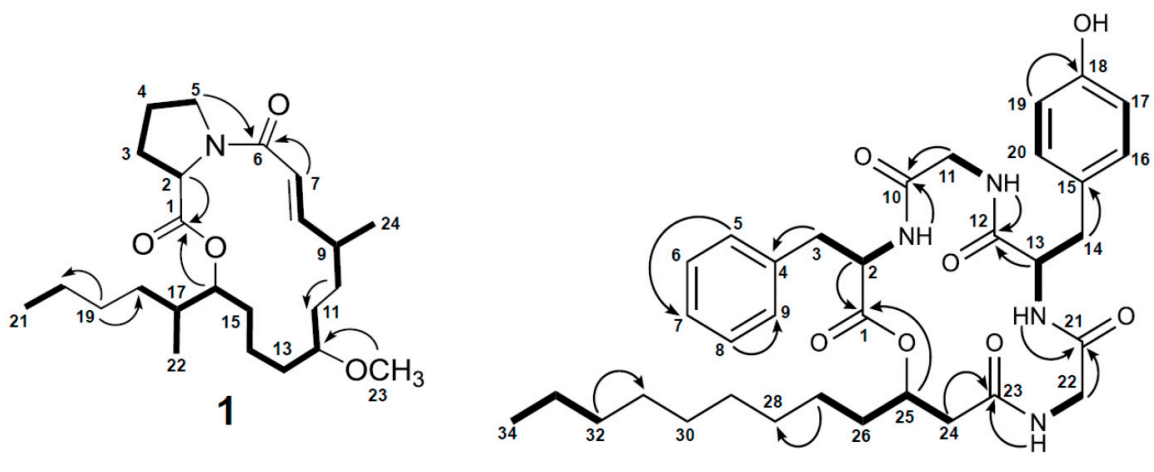

3

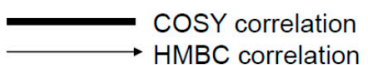

Figure 2. Selected 2D NMR correlations for 1 and 3.

\subsection{Biological Evaluation of $\mathbf{1}-\mathbf{3}$}

No antibacterial activity was observed for 1-3 against the pathogenic strains used in this study and 3 did not demonstrate a 50\% reduction in cell viability against HCT-116 cells and Neuro-2A cells (25 $\mu \mathrm{M}$ dose). Tricholides A (1) and B (2) did not show cytotoxic effects against HCT-116 cells at $25 \mu \mathrm{M}$. However, 2 did show moderately potent cytotoxicity against Neuro-2A neuroblastoma cells $\left(\mathrm{EC}_{50}\right.$ : $14.5 \pm 6.2 \mu \mathrm{M}$ ) (See Figure S28). 1 was not tested against Neuro-2A cells to preserve some amount as a chemical standard. Further work will explore biological activities of 1-3 and search for additional analogs from future Trichodesmium collections.

\section{Discussion}

Tricholides A and B (1 and 2) represent structurally intriguing new additions to macrocylic PKS-NRPS molecules isolated from cyanobacteria collections. These molecules feature a core 15-membered macrolactone reminiscent of palmyrolide A [10] and the laingolides [29]. However, the tricholides feature a 2-methylhexanoic moiety instead of an unusual $t$-butyl branch. Using Tanimoto scoring and database searching, desulfated penarolide sulfate A1 was the most similar molecule to the tricholides [30]. Penarolide A1 is a macrocylic polyketide featuring a single proline residue. However, the core structure of penarolide A1 is a much larger 30-membered ring.

Unnarmicin D (3) showed significant structural similarity to the unnarmicins. 3 contains two chiral amino acids, while the unnarmicins contains four chiral amino acids and 3 contains a longer $\beta$-acyloxy chain than the unnarmicins. When comparing the amino acid and hydroxy acid sequences of five residue depsipeptides with $\beta$-acyloxy functionalities a pattern emerges with respect to the absolute configuration of the individual residues (Table 3 ). The acyloxy group is of the $R$ configuration in all molecules in Table 3 except for turnagainolide B, which contains a rare 3-hydroxy-5-phenyl-4-pentenoic acid in the $S$ configuration [20]. Following a predicted biosynthetic route, the first amino acid in five-residue depsipeptides with $\beta$-acyloxy components is in the L-configuration, the second amino acid is in the D-configuration. The third amino acid is in the L- or D-configuration and the final amino acid is in the L-configuration. Configuration analysis of new metabolites in this class, and determining the absolute configuration of unassigned compounds such as the ngercheumicins, will determine if this pattern, with respect to absolute configurations, continues to hold true.

The configurations of the acyloxy residue listed in all Table 3 examples were determined using the Mosher's method. A computational approach was employed in the configuration analysis of the depsipeptide kailuin B, following equivocal results from derivative analysis using Mosher's method [24]. Theodore et al., used the ${ }^{13} \mathrm{C}$ NMR chemical shifts of a diagnostic set of depsipeptides containing $\beta$-acyloxy groups to provide key insights into ${ }^{13} \mathrm{C}$ NMR $\delta$ values for configuration analysis. 
These ${ }^{13} \mathrm{C}$ NMR values from experimental approaches were combined with computations using density functional theory (DFT) calculations to identify key differences in the $\beta$ and $\gamma$ positions of the $\beta$-acyloxy residue. A diagnostic assessment was proposed in which an $R$ configuration is assigned when $\delta_{\mathrm{C}} \beta \leq 74 / \delta_{\mathrm{C}} \gamma \leq 36$ while an $S$ configuration is assigned when $\delta_{\mathrm{C}} \beta \geq 77 / \delta_{\mathrm{C}} \gamma \geq 40$. The ${ }^{13} \mathrm{C}$ NMR values for the $\beta$ and $\gamma$ positions of 3 are $72.5 \mathrm{ppm}$ and $33.8 \mathrm{ppm}$ respectively. Analysis of the Mosher's ester derivatives of 4 was challenging due to overlapping methylene signals in the Hdda residue and we relied on differences in chemical shift values at H-27, H-26, H-24 and NH-4 for absolute configuration determination. There was no apparent chemical shift difference at H-25. Utilizing the diagnostic approach of Theodore et al., supports the value of these computational approaches and additionally serves as an orthogonal approach to derivitization analysis.

Table 3. Five-residue depsipeptides from marine microbes containing $\beta$-hydroxy acid groups.

\begin{tabular}{ccc}
\hline Compound & Residue Sequence & Source \\
\hline Unnarmicin D (3) & $(R)$-Hdda Gly D-Tyr Gly L-Phe & environmental collection of T. thiebautii \\
Unnarmicin A [17] & $(R)-$ Hha ${ }^{\text {a }}$ L-Leu D-Phe L-Leu L-Phe & Photobacterium sp. strain MBIC0648517 \\
Unnarmicin C [17] & $(R)-$ Hoa $^{b}$ L-Leu D-Phe L-Leu L-Phe & Photobacterium sp. strain MBIC0648517 \\
Solonamide A [18] & $(R)$-Hha L-Phe D-Leu D-Ala L-Leu & Photobacterium sp. strain S275318 \\
Solonamide B [18] & $(R)$-Hoa L-Phe D-Leu D-Ala L-Leu & Photobacterium sp. strain S275318 \\
Arthroamide [19] & $(R)$-Hppa ${ }^{C}$ L-Val D-Ala L-Val L-Val & Arthrobacter sp. strain PGVB119 \\
Turnagainolide A [20] & $(R)$-Hppa L-Val D-Ala L-Ile L-Val & Bacillus sp. strain RJA219420 \\
Turnagainolide B [20] & $(S)$-Hppa L-Val D-Ala L-Ile L-Val & Bacillus sp. strain RJA219420 \\
Ngercheumicin C [21] & Hoa Phe Leu Leu Leu & Photobacterium sp. \\
Ngercheumicin D [21] & Hoa Phe Met Leu Leu & Photobacterium sp. \\
Ngercheumicin E [21] & Hoa Phe Phe Leu Leu & Photobacterium sp. \\
\hline
\end{tabular}

a 3-hydroxy-hexanoic acid; ${ }^{b}$ 3-hydroxy-octanoic acid; ${ }^{c}$ 3-hydroxy-5-phenyl-4-pentenoic acid.

\section{Materials and Methods}

\subsection{General Experimental Procedures}

Optical rotations were measured using a Jasco P-2000 polarimeter (Jasco Inc., Easton, MD, USA). UV spectra were measured using a Beckman Coulter DU-800 spectrophotometer (Beckman Coulter Inc., Brea, CA, USA). NMR spectra were collected using a Bruker $800 \mathrm{MHz}$ NMR instrument (Bruker, Rheinstetten, Germany) equipped with a cryoprobe with $\mathrm{CDCl}_{3}$ and DMSO- $d_{6}$ as the internal standard $\left(\delta_{\mathrm{C}} 77.0, \delta_{\mathrm{H}} 7.26 ; \delta_{\mathrm{C}} 39.5, \delta_{\mathrm{H}} 2.50\right)$. A Varian $500 \mathrm{MHz} \mathrm{NMR}$ spectrometer equipped with a $5 \mathrm{~mm}$, room temperature OneNMR probe was utilized for certain experiments (Varian Inc., Palo Alto, CA, USA). HRESIMS analysis was performed using a AB SCIEX TripleTOF 4600 mass spectrometer (SCIEX, Framingham, MA, USA) with Analyst TF software. Semi-preparative HPLC was carried out using a Dionex Ultimate 3000 HPLC system equipped with a micro vacuum degasser, an autosampler and a diode-array detector (Thermo Scientific, Waltham, MA, USA).

\subsection{Collection of Biological Material}

Samples from a localized bloom of Trichodesmium thiebautii were collected from Padre Island, Corpus Christi, TX during 9-11 May 2014. Surface bloom material was collected in 5-g buckets from ca. 0.5-m water depth. Approximately $300 \mathrm{~g}$ wet weight cell mass was concentrated from this material and frozen for further chemical analysis. In the laboratory, a subsample of the cell mass was examined microscopically and identified using Komarek (2002) [31].

\subsection{Extraction and Isolation}

The frozen biomass was thawed and extracted five times using 2:1 $\mathrm{CH}_{2} \mathrm{Cl}_{2} / \mathrm{CH}_{3} \mathrm{OH}$, affording $3.95 \mathrm{~g}$ of crude extract. The crude extract was further fractionated over silica gel using vacuum liquid chromatography (VLC) and a solvent system of increasing polarity using a stepped gradient from $100 \%$ 
hexanes to $100 \% \mathrm{CH}_{3} \mathrm{OH}$ to generate 9 subfractions (A-I). Two fractions were combined ( $40 \%$ hexanes in ethyl acetate (Fraction E) and 20\% hexanes in ethyl acetate (Fraction F)) based on similarities in their respective ${ }^{1} \mathrm{H}$ NMR spectra. The combined fraction was evaporated under reduced pressure and the resultant residue was applied to a $2 \mathrm{~g} \mathrm{C18} \mathrm{SPE} \mathrm{column} \mathrm{and} \mathrm{eluted} \mathrm{with} 100 \%$ methanol to remove exceedingly lipophilic constituents before HPLC separation. The fraction was subjected to RP semi-preparative HPLC using a YMC $5 \mu \mathrm{m}$ ODS column $(250 \times 10 \mathrm{~mm})$; mobile phase: $85 \%$ $\mathrm{CH}_{3} \mathrm{CN} / 15 \% \mathrm{H}_{2} \mathrm{O}$ with $0.05 \%$ formic acid added to each solvent, flow $3 \mathrm{~mL} / \mathrm{min}$ and $0.3 \mathrm{mg}$ of $\mathbf{1}\left(t_{R}\right.$, $12.8 \mathrm{~min}$ ) and $0.8 \mathrm{mg}$ of $2\left(t_{R}, 14.0 \mathrm{~min}\right)$ were isolated. Two addition fractions, the first eluting with $100 \%$ EtOAc (fraction $\mathrm{G}$ ) and the second eluting with $25 \% \mathrm{CH}_{3} \mathrm{OH}$ in EtOAc (fraction $\mathrm{H}$ ) were combined based on similarities in their ${ }^{1} \mathrm{H}$ NMR spectra and dried using rotary evaporation. The residue was applied to a $2 \mathrm{~g}$ C18 SPE column and fractionated using $50 \% \mathrm{CH}_{3} \mathrm{CN}$ in $\mathrm{H}_{2} \mathrm{O}, 100 \% \mathrm{CH}_{3} \mathrm{CN}$ and $100 \%$ $\mathrm{CH}_{3} \mathrm{OH}$. The fraction eluting with $100 \% \mathrm{CH}_{3} \mathrm{CN}$ was subjected to RP semi-preparative HPLC using a YMC $5 \mu \mathrm{m}$ ODS column $(250 \times 10 \mathrm{~mm})$; mobile phase: $70 \% \mathrm{CH}_{3} \mathrm{CN} / 30 \% \mathrm{H}_{2} \mathrm{O}$ with $0.05 \%$ formic acid added to each solvent, flow $3 \mathrm{~mL} / \mathrm{min}$ and a fraction was collected from $\mathrm{min} 9.5-10.0$. This fraction was further purfied using a YMC $5 \mu \mathrm{m}$ ODS column; mobile phase: $60 \% \mathrm{CH}_{3} \mathrm{CN} / 40 \% \mathrm{H}_{2} \mathrm{O}$ with $0.05 \%$ formic acid added to each solvent, flow $3 \mathrm{~mL} / \mathrm{min}$ and $3.5 \mathrm{mg}$ of 3 were isolated $\left(t_{R}, 19.0 \mathrm{~min}\right)$.

Tricholide A (1): colorless oil; $[\alpha]_{\mathrm{D}}^{23}-10.4(\mathrm{MeOH}, c 0.09)$; UV (MeOH) $\lambda \max (\log \varepsilon) 213(3.9) \mathrm{nm}{ }^{1} \mathrm{H}$ NMR $\left(800 \mathrm{MHz}, \mathrm{CDCl}_{3}\right)$ and ${ }^{13} \mathrm{C}$ NMR $\left(200 \mathrm{MHz}, \mathrm{CDCl}_{3}\right)$ see Table 1 ; HRESIMS $\mathrm{m} / z 408.3113[\mathrm{M}+\mathrm{H}]^{+}$ (calcd. for $\mathrm{C}_{24} \mathrm{H}_{42} \mathrm{NO}_{4}, 408.3114$ ).

Tricholide B (2): colorless oil; $[\alpha]_{\mathrm{D}}^{23}-10.8(\mathrm{MeOH}, c 0.09) ; \mathrm{UV}(\mathrm{MeOH}) \lambda \max (\log \varepsilon) 205(3.5) \mathrm{nm}{ }^{1} \mathrm{H}$ NMR $\left(800 \mathrm{MHz}, \mathrm{CDCl}_{3}\right)$ and ${ }^{13} \mathrm{C} \mathrm{NMR}\left(200 \mathrm{MHz}, \mathrm{CDCl}_{3}\right)$, see Table S1; HRESIMS $m / z$ 222.3276 [M + H] ${ }^{+}$ (calcd. for $\mathrm{C}_{25} \mathrm{H}_{44} \mathrm{NO}_{4}, 422.3270$ ).

Unnarmicin $D(3)$ : white amorphous solids; $[\alpha]_{\mathrm{D}}^{22}-53.3(\mathrm{MeOH}, c 0.07)$; UV (MeOH) $\lambda \max (\log \varepsilon) 201$ (4.09), 221 (3.76), 275 (3.02) nm; ${ }^{1} \mathrm{H}$ NMR (800 MHz, DMSO- $d_{6}$ ) and ${ }^{13} \mathrm{C}$ NMR (200 MHz, DMSO- $\left.d_{6}\right)$, see Table 2; HRESIMS $m / z 623.3436[\mathrm{M}+\mathrm{H}]^{+}$(calcd. for $\mathrm{C}_{34} \mathrm{H}_{47} \mathrm{~N}_{4} \mathrm{O}_{7}, 623.3445$ ).

\subsection{Acid Hydrolysis and Marfey's Protocol}

To determine the absolute configuration of the $\alpha$-amino acids in $1-3,0.2 \mathrm{mg}$ of each compound was reconstituted in $0.2 \mathrm{~mL}$ of $6 \mathrm{~N} \mathrm{HCl}$ and heated at $110{ }^{\circ} \mathrm{C}$ for $15 \mathrm{~h}$. The hydrolyzate was dried in vacuo, reconstituted in $100 \mu \mathrm{L}$ of $0.1 \mathrm{M} \mathrm{NaHCO}_{3}$ solution and treated with $50 \mu \mathrm{L}$ of $1 \mathrm{mg} / \mathrm{mL}$ solution of $N-\alpha$-(2,4-dinitro-5-fluorophenyl)-L-valinamide (L-FDVA) in acetone, followed by heating at $55{ }^{\circ} \mathrm{C}$ for $2 \mathrm{~h}$, cooled to room temperature and quenched with $50 \mu \mathrm{L}$ of $2 \mathrm{~N} \mathrm{HCl}$. The hydrolyzate was dried in vacuo and reconstituted in $100 \mu \mathrm{L}$ of $50 \% \mathrm{CH}_{3} \mathrm{CN} / \mathrm{H}_{2} \mathrm{O}+0.1 \%$ formic acid (FA) and filtered through $0.2 \mu \mathrm{m}$ filter. The hydrolyzate and the L-FDVA derivatized $\alpha$-amino acid standards were subjected to HPLC analysis $\left(20 \% \mathrm{CH}_{3} \mathrm{CN} / \mathrm{H}_{2} \mathrm{O}+0.1 \%\right.$ FA to $80 \% \mathrm{CH}_{3} \mathrm{CN} / \mathrm{H}_{2} \mathrm{O}+0.1 \%$ FA over $30 \mathrm{~min}$; Phenomenex Kinetex C18 column, $150 \times 3 \mathrm{~mm}$, flow $0.6 \mathrm{~mL} / \mathrm{min}$ ). The retention time (min) of the hydrolyzate of $\mathbf{1}$ and $\mathbf{2}$ matched L-Pro (13.00; D-Pro, 14.50). The retention times ( $\mathrm{min}$ ) of the hydrolyzate of 3 matched L-Phe (13.55; D-Phe, 16.18), and D-Tyr (11.75; L-Tyr, 10.45).

\subsection{Hydrolysis of 3}

Unnarmicin D (3) (3.0 mg) was dissolved in 5\% sodium methoxide in $\mathrm{CH}_{3} \mathrm{OH}(2 \mathrm{~mL})$ and stirred for $30 \mathrm{~min}$ at room temperature. The reaction mixture was neutralized by adding $100 \mu \mathrm{L}$ of $1 \mathrm{M} \mathrm{HCl}$. The mixture was evaporated under reduced pressure to remove $\mathrm{CH}_{3} \mathrm{OH}$ and $1 \mathrm{~mL}$ of $\mathrm{H}_{2} \mathrm{O}$ was added to the slurry and extracted three times with EtOAc. After drying with over $\mathrm{Na}_{2} \mathrm{SO}_{4}$, the solvent was removed under reduced pressure and the residue was filtered and subjected to RP-HPLC using a YMC $5 \mu \mathrm{m}$ ODS column $(250 \times 10 \mathrm{~mm})$; mobile phase: $65 \% \mathrm{CH}_{3} \mathrm{CN} / 35 \% \mathrm{H}_{2} \mathrm{O}$ with $0.05 \%$ formic acid added to each solvent, flow $3 \mathrm{~mL} / \mathrm{min}$ and $0.50 \mathrm{mg}$ of 4 was isolated $\left(t_{\mathrm{R}}, 7.0 \mathrm{~min}\right)$. 
Unnarmicin D linear derivative (4): white amorphous solids; ${ }^{1} \mathrm{H}$ NMR (500 MHz, DMSO- $\left.d_{6}\right) \delta 0.85(3 \mathrm{H}, \mathrm{t}$, $J=7.2$ Hz, Hdda, H-34), 1.16 (2H, m, Hdda, H-27) 1.21-1.26 (12H, ovlp, Hdda, H-28-H-33), 1.33 (2H, m, Hdda, H-26), 2.20 (2H, m, Hdda, H-24), 2.63 (1H, m, Tyr, H-14b), 2.85 (1H, m, Tyr, H-14a), 2.87 (1H, m, Phe, H-3b), 3.03 (1H, m, Phe, H-3a), 3.39 (1H, m, Gly-1, H-11b), 3.47 (1H, m, Gly-2, H-22b), 3.59 (1H, m, Gly-2, H-22a), 3.75 (1H, m, Hdda, H-25), 3.80 (1H, m, Gly-1, H-11a), 4.34 (1H, m, Tyr, H-13) 6.61 (2H, d, $J=8.5 \mathrm{~Hz}, \mathrm{Tyr}, \mathrm{H}-17 / 19), 6.96$ (2H, d, $J=8.5 \mathrm{~Hz}, \mathrm{H}-16 / 20) 7.11$ (3H, ovlp, Phe, H-5/9, H-7), 7.15 (2H, m, Phe, H-6/8) 7.32 (1H, m, NH-1), 7.95 (1H, m, NH-3), 8.20 (1H, m, NH-2), 8.35 (1H, m, NH-4); HRESIMS $m / z 663.3366[\mathrm{M}+\mathrm{Na}]^{+}$(calcd. for $\mathrm{C}_{34} \mathrm{H}_{48} \mathrm{~N}_{4} \mathrm{O}_{8}, 663.3370$ ).

\subsection{Preparation of MTPA Esters of $\mathbf{4}$}

$0.25 \mathrm{mg}$ of 4 was dissolved in dry $\mathrm{CH}_{2} \mathrm{Cl}_{2}(0.6 \mathrm{~mL})$ in a $4 \mathrm{~mL}$ vial to which dry pyridine $(10 \mu \mathrm{L})$ and $(S)-(+)-\alpha$-methoxy- $\alpha$-(trifluoromethyl)phenylacetyl chloride $(15 \mu \mathrm{L})$ were added. The identical procedure was repeated with an equal amount of 4 and $(R)-(-)-\alpha$-methoxy- $\alpha-$ (trifluoromethyl)phenylacetyl chloride. The vials were capped and the reaction mixtures were stirred for $24 \mathrm{~h}$. The reactions were quenched with $\mathrm{H}_{2} \mathrm{O}$ and separated using $\mathrm{CH}_{2} \mathrm{Cl}_{2}$ and $\mathrm{H}_{2} \mathrm{O}$. The $\mathrm{CH}_{2} \mathrm{Cl}_{2}$ layer was evaporated under reduced pressure and the derivatives were subjected to ${ }^{1} \mathrm{H}$ NMR analysis.

\subsection{Antimicrobial Assay}

\subsubsection{Bacterial Strains}

Methicillin-resistant Staphylococcus aureus (MRSA, ATCC 43300), Pseudomonas aeruginosa PAO1, and Escherichia coli (ATCC 35218) were employed for antimicrobial activities.

\subsubsection{Antimicrobial Activity}

The antimicrobial properties of 1-3 were tested via broth dilution assay. Compounds were prepared in DMSO at $5 \mathrm{mg} / \mathrm{mL}$. Tetracycline and gentamycin were used as positive controls. Minimal inhibitory concentrations (MICs) were determined using the broth microdilution method. Briefly, pathogens were firstly inoculated into tryptic soy broth (TSB, BD, Franklin Lakes, NJ, USA) at $37^{\circ} \mathrm{C}$ and shaken at $175 \mathrm{rpm}$ overnight. The bacterial broth $\left(1 \times 10^{8}\right.$ colony-forming units $\left.(\mathrm{CFU}) / \mathrm{mL}\right)$ was immediately diluted to $1 \times 10^{5} \mathrm{CFU} / \mathrm{mL}$. In 96-well microtiter plates, $5 \mu \mathrm{L}$ of compounds and controls were mixed well with $195 \mu \mathrm{L}$ of bacterial suspension $(1: 39(v / v))$. After a series of two-fold dilutions, the microtiter plates were then incubated statically at $37^{\circ} \mathrm{C}$ overnight. MICs were determined as the minimal concentration at which no visible bacterial growth was present. No antimicrobial activity was observed for compounds $\mathbf{1}-\mathbf{3}$.

\subsection{Cytotoxicity Assay}

HCT-116 cells and Neuro-2A cells were added to 96 well plates in $100 \mu \mathrm{L}$ of McCoy's Media and Eagle's Minimum Essential Media (EMEM) respectively each supplemented with $10 \%$ FBS each at a density of 5000 cells/well. Cells were incubated overnight $\left(37{ }^{\circ} \mathrm{C}, 5 \% \mathrm{CO}_{2}\right)$ and examined microscopically to confirm confluence and adherence. Purified 1-3 were dissolved in DMSO $(1 \% v / v)$ and added to the cells in the range of 100, 10, 1, 0.1 and $0.01 \mu \mathrm{M}$. Four technical replicates were prepared for each concentration and the assay was performed in triplicate. Doxorubicin was used as the positive control $\left(\mathrm{EC}_{50}\right.$ :Neuro-2A $=100 \pm 5.2 \mathrm{nM}$ ). Plates were incubated for $72 \mathrm{~h}$ after which $15 \mu \mathrm{L}$ of MTT dye were added each assay well. The dye was allowed to incubate with the cells for $4 \mathrm{~h}$ after which the media was aspirated and the remaining crystals were solubilized in $100 \mu \mathrm{L}$ DMSO. The plates were incubated at $37^{\circ} \mathrm{C}$ for $30 \mathrm{~min}$ to allow the crystals to solubilize. Absorbance at $540 \mathrm{~nm}$ was measured using a Molecular Devices SpectraMax plate reader and \% viability was calculated compared to the negative control (1\% DMSO) and $\mathrm{EC}_{50}$ curves were generated using GraphPad Prism 6. 
Supplementary Materials: The following are available online at www.mdpi.com/1660-3397/15/7/206/s1, Table S1: NMR data for 2; Figures S1-S21: ${ }^{1} \mathrm{H}$ NMR, ${ }^{13} \mathrm{C}$ NMR, HSQC, HMBC, COSY, TOCSY and NOESY spectra of 1-3; Figures S22-S24: Marfey's L-FDVA derivatives of the hydrolyzate of 1-3 compared to L-FDVA amino acid standards. Figures S25 and S26: ${ }^{1} \mathrm{H}$ NMR and COSY of 4. S27: $\Delta\left(\delta_{\mathrm{H}} S-\delta_{\mathrm{H}} R\right)$ values of $S$-MTPA and $R$-MTPA esters of 4 . Figure S28. EC $_{50}$ curve of 2 tested against Neuro-2A cells.

Acknowledgments: Funding in part provided by NSF/NIEHS R01 ES21968-1 awarded to PVZ. We thank I-Shuo Huang for field collection assistance. Research reported in this publication was made possible by the use of equipment and services available through the RI-INBRE Centralized Research Core Facility at the University of Rhode Island, which is supported by the Institutional Development Award (IDeA) Network for Biomedical Research Excellence from the National Institute of General Medical Sciences of the National Institutes of Health under grant number P20GM103430. Certain NMR experiments were conducted at a research facility at the University of Rhode Island supported in part by the National Science Foundation EPSCoR Cooperative Agreement \#EPS-1004057.

Author Contributions: M.J.B., P.V.Z. and P.D.R.M. conceived and designed the experiments; A.F.R., J.S., G.E.A., C.W.V. and M.A.G. performed the experiments; M.J.B. and J.S. analyzed the data; P.V.Z. contributed reagents/materials/analysis tools; M.J.B. wrote the paper.

Conflicts of Interest: The authors declare no conflict of interest.

\section{References}

1. Tan, L.T. Pharmaceutical agents from filamentous marine cyanobacteria. Drug Discov. Today 2013, 18, 863-871. [CrossRef] [PubMed]

2. Tan, L.T. Bioactive natural products from marine cyanobacteria for drug discovery. Phytochemistry 2007, 68, 954-979. [CrossRef] [PubMed]

3. Nunnery, J.K.; Mevers, E.; Gerwick, W.H. Biologically active secondary metabolites from marine cyanobacteria. Curr. Opin. Biotechnol. 2010, 21, 787-793. [CrossRef] [PubMed]

4. Gerwick, W.H.; Moore, B.S. Lessons from the past and charting the future of marine natural products drug discovery and chemical biology. Chem. Biol. 2012, 19, 85-98. [CrossRef] [PubMed]

5. Luesch, H.; Yoshida, W.Y.; Moore, R.E.; Paul, V.J.; Mooberry, S.L. Isolation, structure determination, and biological activity of Lyngbyabellin A from the marine cyanobacterium Lyngbya majuscula. J. Nat. Prod. 2000, 63, 611-615. [CrossRef] [PubMed]

6. Kang, H.S.; Krunic, A.; Orjala, J. Sanctolide A, a 14-membered PK-NRP hybrid macrolide from the cultured cyanobacterium Oscillatoria sancta (SAG 74.79). Tetrahedron Lett. 2012, 53, 3563-3567. [CrossRef] [PubMed]

7. Belakhov, V.V.; Garabadzhiu, A.V. Polyene macrolide antibiotics: Mechanisms of inactivation, ways of stabilization, and methods of disposal of unusable drugs. Russ. J. Gen. Chem. 2015, 85, 2985-3001. [CrossRef]

8. Kollár, P.; Rajchard, J.; Balounová, Z.; Pazourek, J. Marine natural products: Bryostatins in preclinical and clinical studies. Pharm. Biol. 2014, 52, 237-242. [CrossRef] [PubMed]

9. Shao, C.L.; Linington, R.G.; Balunas, M.J.; Centeno, A.; Boudreau, P.; Zhang, C.; Engene, N.; Spadafora, C.; Mutka, T.S.; Kyle, D.E.; et al. Bastimolide A, a Potent Antimalarial Polyhydroxy Macrolide from the Marine Cyanobacterium Okeania hirsuta. J. Org. Chem. 2015, 80, 7849-7855. [CrossRef] [PubMed]

10. Pereira, A.R.; Cao, Z.Y.; Engene, N.; Soria-Mercado, I.E.; Murray, T.F.; Gerwick, W.H. Palmyrolide A, an unusually stabilized neuroactive macrolide from palmyra atoll cyanobacteria. Org. Lett. 2010, 12, 4490-4493. [CrossRef] [PubMed]

11. Moore, R.E. Cyclic peptides and depsipeptides from cyanobacteria: A review. J. Ind. Microbiol. 1996, 16, 134-143. [CrossRef] [PubMed]

12. Kehr, J.C.; Picchi, D.; Dittmann, E. Natural product biosyntheses in cyanobacteria: A treasure trove of unique enzymes. Beilstein J. Org. Chem. 2011, 7, 1622-1635. [CrossRef] [PubMed]

13. Welker, M.; von Döhren, H. Cyanobacterial peptides-Nature's own combinatorial biosynthesis. FEMS Microbiol. Rev. 2006, 30, 530-563. [CrossRef] [PubMed]

14. Elsworth, J.F.; Grove, J.F. Cyclodepsipeptides from Beauveria bassiana Bals. Part 1. Beauverolides H and I. J. Chem. Soc. Perkin Trans. 1 1977, 3, 270-273. [CrossRef]

15. Elsworth, J.F.; Grove, J.F. Cyclodepsipeptides from Beauveria bassiana. Part 2. Beauverolides A to F and their relationship to isarolide. J. Chem. Soc. Perkin Trans. 1 1980, 8, 1795-1799. [CrossRef]

16. Grove, J.F. Cyclodepsipeptides from Beauveria bassiana. Part 3. The isolation of beauverolides $\mathrm{Ba}, \mathrm{Ca}, \mathrm{Ja}$, and Ka. J. Chem. Soc. Perkin Trans. 1 1980, 12, 2878-2880. [CrossRef] 
17. Oku, N.; Kawabata, K.; Adachi, K.; Katsuta, A.; Shizuri, Y. Unnarmicins A and C, new antibacterial depsipeptides produced by marine bacterium Photobacterium sp. MBIC06485. J. Antibiot. 2008, 61, 11-17. [CrossRef] [PubMed]

18. Månsson, M.; Nielsen, A.; Kjaerulff, L.; Gotfredsen, C.H.; Wietz, M.; Ingmer, H.; Gram, L.; Larsen, T.O. Inhibition of virulence gene expression in Staphylococcus aureus by novel depsipeptides from a marine photobacterium. Mar. Drugs 2011, 9, 2537-2552. [CrossRef] [PubMed]

19. Igarashi, Y.; Yamamoto, K.; Fukuda, T.; Shojima, A.; Nakayama, J.; Carro, L.; Trujillo, M.E. Arthroamide, a cyclic depsipeptide with quorum sensing inhibitory activity from Arthrobacter sp. J. Nat. Prod. 2015, 78, 2827-2831. [CrossRef] [PubMed]

20. Li, D.; Carr, G.; Zhang, Y.; Williams, D.E.; Amlani, A.; Bottriell, H.; Mui, A.L.-F.; Anderson, R.J. Turnagainolides A and B, cyclic depsipeptides produced in culture by a Bacillus sp.: Isolation, structure elucidation, and synthesis. J. Nat. Prod. 2011, 74, 1093-1099. [CrossRef] [PubMed]

21. Adachi, K.; Kawabata, Y.; Kasai, H.; Katsuta, M.; Shizuri, Y. New Antibiotic. Japanese Patent JP 2007230911, 13 September 2007.

22. Krunic, A.; Vallat, A.; Mo, S.; Lantvit, D.D.; Swanson, S.M.; Orjala, J. Scytonemides A and B, cyclic peptides with 20 S proteasome inhibitory activity from the cultured cyanobacterium Scytonema hofmanii. J. Nat. Prod. 2010, 73, 1927-1932. [CrossRef] [PubMed]

23. Harrigan, G.G.; Harrigan, B.L.; Davidson, B.S. Kailuins A-D, new cyclic acyldepsipeptides from cultures of a marine-derived bacterium. Tetrahedron 1997, 53, 1577-1582. [CrossRef]

24. Theodore, C.M.; Lorig-Roach, N.; Still, P.C.; Johnson, T.A.; Drašković, M.; Schwochert, J.A.; Naphen, C.N.; Crews, M.S.; Barker, S.A.; Valeriote, F.A.; et al. Biosynthetic products from a nearshore-derived gram-negative bacterium enable reassessment of the kailuin depsipeptides. J. Nat. Prod. 2015, 78, 441-452. [CrossRef] [PubMed]

25. Sudek, S.; Haygood, M.G.; Youssef, D.T.A.; Schmidt, E.W. Structure of trichamide, a cyclic peptide from the bloom-forming cyanobacterium Trichodesmium erythraeum, predicted from the genome sequence. Appl. Environ. Microbiol. 2006, 72, 4382-4387. [CrossRef] [PubMed]

26. Bertin, M.J.; Wahome, P.G.; Zimba, P.V.; He, H.; Moeller, P.D.R. Trichophycin A, a cytotoxic linear polyketide isolated from a Trichodesmium thiebautii bloom. Mar. Drugs 2017, 15, 10. [CrossRef] [PubMed]

27. Bertin, M.J.; Zimba, P.V.; He, H.; Moeller, P.D.R. Structure revision of trichotoxin, a chlorinated polyketide isolated from a Trichodesmium thiebautii bloom. Tetrahedron Lett. 2016, 57, 5864-5867. [CrossRef]

28. Hove, T.R.; Jeffrey, C.S.; Shao, F. Mosher ester analysis for the determination of absolute configuration of stereogenic (chiral) carbinol. Nat. Protoc. 2007, 2, 2451-2458.

29. Klein, D.; Braekman, J.C.; Daloze, D.; Hoffman, L.; Castillo, G.; Demoulin, V.V. Madangolide and laingolide A, two novel macrolides from Lyngbya bouillonii (Cyanobacteria). J. Nat. Prod. 1999, 62, 934-936. [CrossRef] [PubMed]

30. Nakao, Y.; Maki, T.; Matsunaga, S.; van Soest, R.V.M.; Fusetani, N. Penarolide sulfates $\mathrm{A}_{1}$ and $\mathrm{A}_{2}$, new $\alpha$-glucosidase inhibitors from a marine sponge Penares sp. Tetrahedron 2000, 56, 8977-8987. [CrossRef]

31. Komárek, J.; Anagnostidis, K. Cyanoprokarota 19 Part 2: Oscillatoriales; Elsevier: München, Germany, 2005; pp. 1-759.

(C) 2017 by the authors. Licensee MDPI, Basel, Switzerland. This article is an open access article distributed under the terms and conditions of the Creative Commons Attribution (CC BY) license (http://creativecommons.org/licenses/by/4.0/). 